\title{
A STRUCTURED WORKSHOP: AN ENDEAVOR TO IMPROVE TEACHERS COMPETENCE IN WRITING SCIENTIFIC JOURNAL ARTICLES
}

\author{
Afrianto Daud ${ }^{1}$, Ando Fahda Aulia ${ }^{2}$, Nita Rimayanti ${ }^{3}$, Mirza Hardian ${ }^{4}$ \\ ${ }^{1,4}$ Faculty of Teachers Training and Education, Universitas Riau \\ ${ }^{2}$ Faculty of Economics and Business, Universitas Riau \\ ${ }^{3}$ Faculty of Social Science and Politics, Universitas Riau
}

Corresponding Author: afrianto.a@lecturer.unri.ac.id

\begin{tabular}{l}
\hline Article Info \\
\hline Received : 28 September 2020 \\
Accepted : 08 October 2020 \\
Published : 22 October 2020
\end{tabular}

Keywords: Scientific Writing, Journal Article, Teachers' Professionalism, Writing Skills

\begin{abstract}
The ability to write and publish articles in scientific journals is part of the professional competence of the teacher. The problem is that many teachers have not mastered the skills of writing scientific papers. As a result, many teachers find it difficult to advance in rank, especially for promotion after IV/a. This paper describes a community service activity sponsored by Riau University lecturers which aims to help teachers improve their scientific writing skills. Community Service Activities were performed at a SMAIT (Islamic Integrated High School) in Pekanbaru, Riau. This paper further explains the concept of the workshop, the content of the workshop materials, and the effectiveness of the workshop. This workshop lasted for two months with three face-to-face training sessions. The rest was done online via the Google Classroom platform. The material content covers the basic principles of scientific writing, the steps for writing scientific journals, how to cite and make references, including how to automatically quote from reference manager applications such as Mendeley, and how to submit articles through the Online Journal System (OJS). Data from the survey conducted at the end of the community service activity showed that, in general, this activity was well and effectively carried out. The majority of participants $(72.7 \%)$ stated that their motivation to write increased after attending the training. Their knowledge of writing scientific articles have improved after training. Their ability in writing scientific journals is also relatively better than before following this structured workshop.
\end{abstract}

International Journal of Educational Best Practices (IJEBP)

Vol. 4 No. 2 October 2020

ISSN: 2581-0847

DOI: $10.32581 /$ ijebp.v4n2.p88-99 


\section{INTRODUCTION}

The teacher is the key and plays a primary role in carrying out the educational process. Ideal curriculum design, complete educational facilities or infrastructure, sophisticated rules of the system, or legal instruments will not have much effect on the success of education if it is not supported by the readiness of teachers in the field (Palmer, 1999). For this rationale, it is appropriate for the Indonesian Government to pay great attention to the professionalization effort of the teacher over the last ten years, especially following the enactment of Law 14/2005 on teachers and lecturers. Afterward, becoming a professional teacher becomes an important issue for all stakeholders in Indonesian education.

The Indonesian government has made some efforts to overcome the problem of lowquality education. Improving the quality of teachers is the best way to start developing the quality of education. The existence of professional teachers has a vital role so that each teacher must constantly improve their professionalism. One of the efforts that need to be designed in order to increase the professional competence of teachers is the movement to write scientific papers. This is in line with the Law of the Republic of Indonesia No. 14 of 2005 on Teachers and Lecturers, Article 20, Part B, which states that in carrying out their professional duties, teachers are obliged to improve and develop academic qualifications and competencies on a continuous basis in line with the development of science, technology, and art so that the ability to write scientific papers is very important to the advancement of professionalism as a teacher.

Teachers who are unable to write will experience communication problems because, in carrying out daily tasks, teachers are required to be able to write, such as writing official letters, writing activity reports, and writing scientific papers for promotion (Keraf, 1996). Essentially, the ability to write scientific papers is an absolute skill that should be mastered by teachers, especially for professional development in the performance of tasks such as the ability of teachers to write and publish scientific papers in scientific journals, which is an effort to gain a credit score that can be used for career advancement requirements or promotion.

However, reality shows that many teachers experience difficulties in moving from Group IV/a to Group IV/b, which are required to have scientific work. The latest Regulation on the promotion of teachers (Permenpan No. 16/2009) also requires teachers to have a credit score for scientific writing and publication since their promotion from III/B to III/C.

\section{International Journal of Educational Best Practices (IJEBP)}

Vol. 4 No. 2 October 2020

ISSN: 2581-0847

DOI: $10.32581 /$ ijebp.v4n2.p88-99 
The challenges faced by teachers are the lack of motivation for writing scientific papers and the lack of understanding about technical aspects of writing scientific papers. This is due to the work of teachers and lack of free time to write scientific papers. According to Daud (Daud, 2007), the lack of motivation to write and the lack of knowledge of the technical aspects of writing scientific papers is a cause for many teachers in Pekanbaru whose promotion has stopped in IV/a class. Therefore, it is important to continue developing the activity of writing scientific papers for teachers.

In general, the ability of junior and senior high school teachers in Indonesia to write scientific papers is still very low. Several studies conducted by other researchers, such as the study by Bunyamin (2016) which measured the level of teacher competence in Jakarta showed that the level of teacher ability in writing scientific papers was still low. A similar study was conducted by Marwan (2017) on English teachers in Pontianak. Another study was done by Zulkifli (2016) in Pekanbaru. The results show that the majority of teachers find it difficult to publish in accredited national journals.

The difficulties of writing academic papers are not only experienced by teachers, but also by graduate students in universities (Azizah \& Budiman, 2017). Yet, this paper focuses only on teachers. Teachers' lack of ability in writing journal articles happens for several reasons. First of all, the teachers lack information sources, such as books and journals. This was confirmed by a number of junior and senior high school teachers we met prior to the training. The teachers do not have books or journals, so it is difficult for them to support their writings with current theories. Second, the teachers generally have no research results or ideas to write about. This is closely related to the first problem, which includes the lack of available sources of information in the form of books and journals about education as well as supervision carried out by the Principal to improve and develop the quality of the learning process and the school as a system. Third, the ability of the teachers to write or express ideas in writing is generally still low. In general, middle and high school teachers are not used to do the writing. Writing scientific articles requires practice and habits and broad insights in order to develop new ideas. These skills are not acquired by genetic means but are acquired through a process of learning and practice.

Finally, the difficulties experienced by junior and senior high school teachers are their lack of understanding of the concept of scientific writing in the writing of scientific journals. It can be seen through the use of very long titles, even likening research titles into article titles. Another obstacle is the way of making abstracts that should be available in every scientific journal with more than 200 words and the use of a number of keywords. In the introduction, the theoretical description is usually too long and uses expert opinion in order to be a quotation, but it is not followed by citation rules in accordance with the applicable rules so that it leads to plagiarism.

International Journal of Educational Best Practices (IJEBP)

Vol. 4 No. 2 October 2020

ISSN: 2581-0847

DOI: $10.32581 /$ ijebp.v4n2.p88-99 
Scientific work can be classified into 2, which include (a) scientific papers on research reports and (b) scientific papers from scientific reviews. These scientific works may be presented in the form of books, textbooks, modules, translated works, papers, journal articles, or articles in mass media. According to Widoyoko (2008), there are different types of scientific work, such as (a) research, (b) scientific essays, (c) popular scientific work, (d) seminars, (e) books, (f) textbooks, and (g) translations.

It is an obligation for any research work containing scientific truth, the truth that is not only based on reason but can also be proven empirically (Nana Sudjana, 1987). Rationalism is based on reason or reasoning, whereas empiricism is based on evidence or facts. Scientific thinking means combining rational and empirical thinking. The operationalization of scientific thinking is called scientific research, while the results of the application of the scientific method are called scientific works. Therefore, not all written works can be considered as scientific works.

Zemach and Rumisek (2005) suggest that the process of writing scientific papers is carried out in several stages, namely: (a) the pre-writing stage, including brainstorming and making outlines, (b) the writing stage, and (c) the revision stage. The prewriting stage is a planning or preparation process, including identification of the problems, selection of references, and drafting the outlines. By describing each main idea in the outline, the writing stage is the development of the framework into a complete composition. The revision stage is an improvement in content, the structure of writing, grammar, and spelling. It is not only made by the author but may also be performed by other people or reviewers.

Middle and high school teachers should be able to generate innovative ideas that can be disseminated to fellow teachers as a source of recent references. If the teacher can generate innovative ideas and share them with other school teachers, then those ideas will be shared by other teachers. In other words, the sharing process (giving and receiving) will be sustainable. This is what the scientific community and the learning community are called. The expected output of this $P K M$ activity is scientific articles that are ready to be published in scientific journals and the establishment of at least one scientific journal independently managed by junior high school and high school teachers in Pekanbaru.

Thus, the formulation of the problems to be answered in this paper is organized as follows. 1) How to enhance the ability of teachers to write and publish scientific works? 2) What skills do the teachers need in writing and publishing scientific papers? 


\section{METHODOLOGY}

The researchers performed community service activities through several methods in order to answer the above-mentioned problems. The Structured Workshop Series is the first method. Workshops were held between an online and offline combination due to the distancing and closure of the teaching and learning process due to Covid for 2 months (August-September 2020).

Workshop activities began by guiding access to various free, easy-to-use reference sources, followed by an update on the urgency of conducting research and publishing research results for teachers that were conducted three times. In the first session, there was an explanation of the research description that could be carried out in a school setting, guidance in formulating the problems, finding relevant reference sources, and research methodology that is suitable for the formulation of the problem. As a result, there is a research design produced by teachers.

The participants were trained to use the Mendeley application in making automatic citations and references in the second session of the workshop. Mendeley is reference management (reference manager) application that can be used for free. This software helps an author to find, store, and integrate references in writing into citations and bibliography. All citation processes can be performed automatically by using the application and no need to memorize detailed rules for each reference style type, such as APA, Harvard, IEEE, and others.

During the third session, the workshop was held in the form of giving feedback on the manuscript draft produced by the teacher. Feedback is provided online via Google Classroom and also during offline meetings. During this last session, participants were also trained on how to submit articles to accredited national journals. At least one teacher's writing, which can be published in an accredited national journal in collaboration with lecturers, becomes the output target of this training.

The second method is mentoring. The activities were carried out in the classroom combined with the Google Classroom, which aims to provide tutorials and supervision to assist teachers in the pre-writing process until the publication of the scientific articles. Community service by students (Kukerta) from Riau University was also included in this activity. Then the third is a survey of perception. The survey was conducted to measure the effectiveness and feedback of teachers at workshops. This survey was presented in the form of a questionnaire consisting of some closed and open questions (see attachment). The effectiveness of the program is analyzed by comparing the responses of participants before and after training.

\section{International Journal of Educational Best Practices (IJEBP)}

Vol. 4 No. 2 October 2020

ISSN: 2581-0847

DOI: $10.32581 /$ ijebp.v4n2.p88-99 


\section{DISCUSSION}

Scientific writing seems to be a challenging task since it requires a number of skills that are quite complex, such as understanding the content, having good written language skills, understanding the technicalities of scientific writing which are often complex and rigid, up to the publication process, including technical issues related to the submission and understanding the type and quality of the intended journal.

These are the reasons why writing scientific publications is a threat to some teachers. Some of them choose to hold on to the promotion for a long time rather than to write scientific work. Consequently, many teachers are stagnating at certain levels, especially civil servant (PNS) teachers. Then, a workshop with structured material becomes important to be implemented. A two-month workshop was given as one of the authors' attempts to assist teachers in writing scientific journals that focus on three journal writing activities: pre-writing activities, while writing, and post-writing (submitting) papers to the intended journal.

\section{Pre-writing}

Teachers were prepared to practice their papers at the pre-writing stage. Planning is the beginning of everything, and if it fails, it means that the writer is planning to fail in writing. Many papers have been rejected by the journals due to insufficient planning. There is some planning that needs to be done before starting to write a scientific paper. First, determine the type of writing. A writer should think about what kind of writing whether it is a research paper or a non-research paper, or a review of the literature. Second, decide the subject of the writing. The subject of writing is the heart of what we are trying to express in a scientific article. The subject should be based on the author's expertise and be compatible with the intended journal. Third, find the hook to draw readers. A hook must be considered to increase the rating of readers and improve branding as the author of scientific articles. Fourth, think about the interests of the journal. From the beginning, it is necessary to ask the question "Will the journal be interested in receiving my article?" In this case, the author may study the scope of the journal to be addressed, including the specific rules of the journal. It will be discussed in the following sections.

Teachers were also trained to select a journal after planning. Currently, there are several types of journals focusing on the subject of writing. There are usually four types of journals, including 1) journals with particular subjects versus general subjects. There are publications that publish papers on very particular subjects, such as early childhood

International Journal of Educational Best Practices (IJEBP)

Vol. 4 No. 2 October 2020

ISSN: 2581-0847

DOI: $10.32581 /$ ijebp.v4n2.p88-99 
education publications, geology science journals, dental and oral journals. However, some journals publish only general subjects, such as educational science journals; 2) Research-based (qualitative vs quantitative). Some journals accept only qualitative research or only quantitative research, or both research writing. An author needs to be aware of the preferences of the intended journal; 3) High impact vs low impact. Journals also have their respective popularity levels. If the journal is frequently cited by other authors in writing their research papers, it is categorized as a high impact journal. Otherwise, if the journal is slightly quoted by the public, the journal is included as a low impact journal. Journals with a high influence have stringent publishing guidelines. Unsurprisingly, the papers are considered to be prestigious.

Another essential thing to consider during this process is an effort to discover the reputation of the journals. It should be acknowledged that not all journals are credible. There are also publications that can manipulate the authors. It would be better for the author to know basic information about national and international scientific journals. Generally, journals are divided into two: national journals and international journals. National journals are divided into two more: national accredited journals and national unaccredited journals. There are a number of criteria for a publication to be accredited. These journals must be published by professional scientific associations or organizations, or in cooperation with universities or other institutions; the scientific journals must have sustainable partners from different institutions; the journals must have an e-ISSN and a variety of other requirements. The accredited national journals are divided into six levels: Sinta 1-Sinta d (S1-S6), the list can be seen at www.sinta.ristekbrin.go.id.

Meanwhile, there are two divisions of international journals: reputable international journals and non-reputable international journals. The reputation of an international journal is marked by the number of citations of other authors in the article in the journal. Typically, it is indexed by world indexing organizations such as Scopus, Science Citation Index (SCI), Social Science Citation Index (SSCI), Arts and Humanities Science Index (AHSI), ISI Thomson, Google Scholar, and others.

The world's well-known indexing institutions, such as Scopus, classify international journals as four: Quartile 1-Quartile 4 (Q1-Q4). In general, the quartile journal shall be determined by the total number of citations in one year divided by the number of journal documents in one year. The more citation of the journal, the higher the rating of the quartile. Currently, the guidelines for the promotion of lecturers in Indonesia require lecturers to publish in journals categorized as reputable journals. 


\section{While writing}

After performing out a number of activities in the writing preparation phase, the participants moved to the writing stage, the central stage of the scientific writing process. At this point, they were introduced to the structure of the article in the journal. Scientific articles have "bones" to form a framework for scientific writing, just as human bones make up the body's skeleton. If one of these parts is missing, a complete and perfect scientific article will not be completed. The core parts of the scientific work are title, abstract, introduction, methodology, results and discussions, and conclusions.

An author needs to create an eye-catching title that attracts the attention of potential readers. A good title should not be more than fifteen keywords from the content of the article which are intended to explain the content of the scientific paper in a compact and concise manner. Through the interesting keywords in the title, there is a potential to make a person's scientific work can be accessed and read by a larger audience.

Furthermore, the participants learned how to make a good abstract. An abstract is the most important part that becomes the main target of readers in the search for literature that comes from journals because abstracts generally describe research based on research objectives, methods, working principles, brief theory, results, and conclusions. Thus, the journal writer must be good at writing short and concise abstracts.

After writing the abstract, the participants learned how to make an introduction to the journal. The introduction usually contains some background as to why the subject is important. The first paragraph should contain a brief summary of recent research in the past. This should be directly related to the second paragraph, which summarizes what other researchers have done in this area, such as what boundaries have been met and what questions still need answers. Then, the last paragraph should clearly state what you have done and the reason.

In general, the methodology describes the design of the research that has been carried out to answer research questions. The workshop participants learned about writing the journal methodology, which includes describing research design, population and research samples, data collection methods, data analysis techniques, and other issues related to research methodological aspects such as location and time of research.

Then, the participants came to the most important part of the scientific work, writing the findings and discussion. The function of this section is to provide specific answers to the research question referred to in the introduction. In this section, the author may use text, tables, and images to explain the findings on the answers to the research questions.

International Journal of Educational Best Practices (IJEBP)

Vol. 4 No. 2 October 2020

ISSN: 2581-0847

DOI: $10.32581 /$ ijebp.v4n2.p88-99 
It is essential for the scientific paper to have a discussion of the findings. The discussion of the article should reiterate the main purpose of the research and explain how the findings fit into existing science, compare and contrast with other studies in the same field. The author also needs to explain new things about his research. In addition, the authors need to explore the various implications of these findings for future research.

The conclusion is the final part of the paper. The workshop participants were trained to draw good conclusions from their writing. A general summary of research results related to the research question should be provided in the conclusion. Then, it is necessary to write briefly the implications of the research results for the enrichment of knowledge and for a message that the reader can take from the writing.

In addition to the discussion of the above sections, the workshop sessions also discussed and trained teachers on how to make citations and make references based on citations and reference standards that apply in the academic world. Participants made direct and indirect quotations in popular standard citations such as APA 6th Style, Harvard, IEEE, and Turabian Style. Following the concepts of some of these forms of quotations, the participants also worked on Mendeley, a reference manager application, to do all of this automatically.

\section{Post writing}

The closing material of this workshop is the submission of articles to the intended journal in the Open Journal System. In this section, participants are taught on the details of journal websites, creating an OJS account, uploading manuscripts, checking the progress of the review on OJS, and collecting manuscripts if there are suggestions for improvement from the reviewers.

Sometimes the journal reviewing is a long process. Thus, some motivational suggestions were also presented at the end of the session. A writer needs a persistent mental attitude in the writing of a journal until the journal is published. Since the process can take a long time and require patience and struggle, only those who are persistent, never give up, are finally able to publish their paper in the journals.

\section{The Outcomes of the Training}

At the end of the workshop session, a questionnaire was distributed by the Community Service Team to see the impact of this workshop on the improvement of the teachers. Since writing skills can not immediately see progress in a short time, the survey looks more closely at participants ' perceptions of their increased motivation and

\section{International Journal of Educational Best Practices (IJEBP)}

Vol. 4 No. 2 October 2020

ISSN: 2581-0847

DOI: 10.32581/ijebp.v4n2.p88-99 
understanding on the matter of scientific journal writing, as illustrated in the following graph:

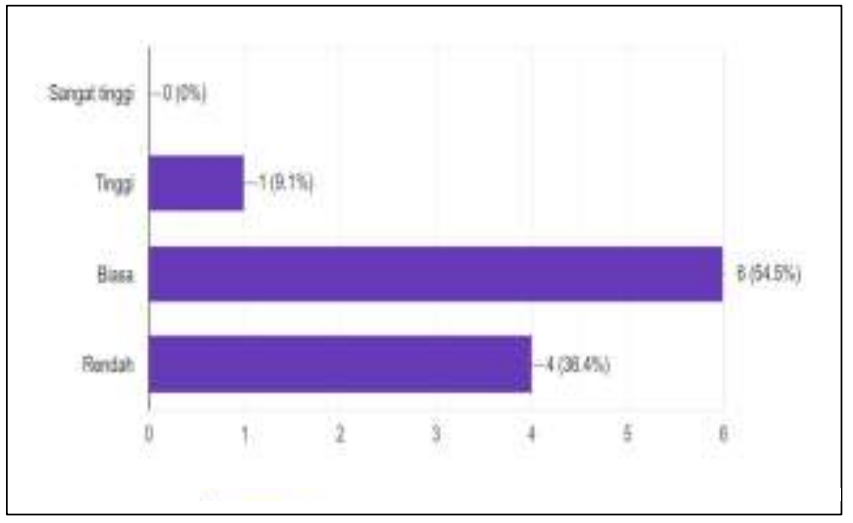

Before

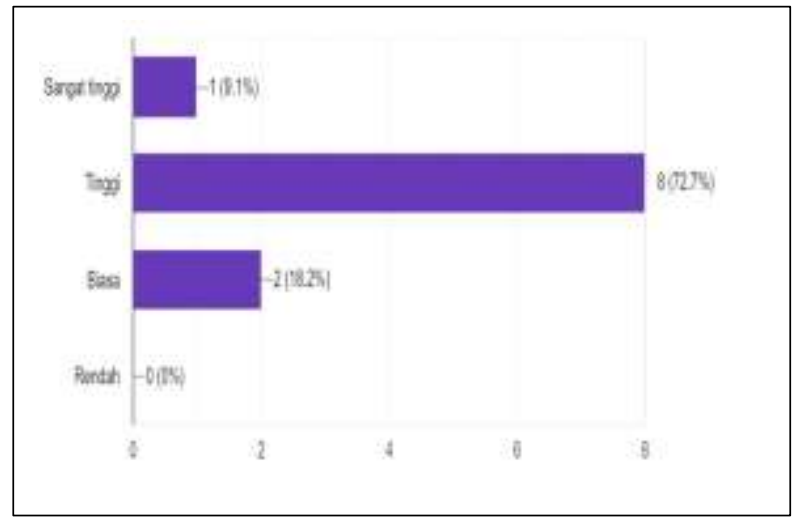

After

Figure 1: Teachers' Motivation on Journal Writing Before and After Training

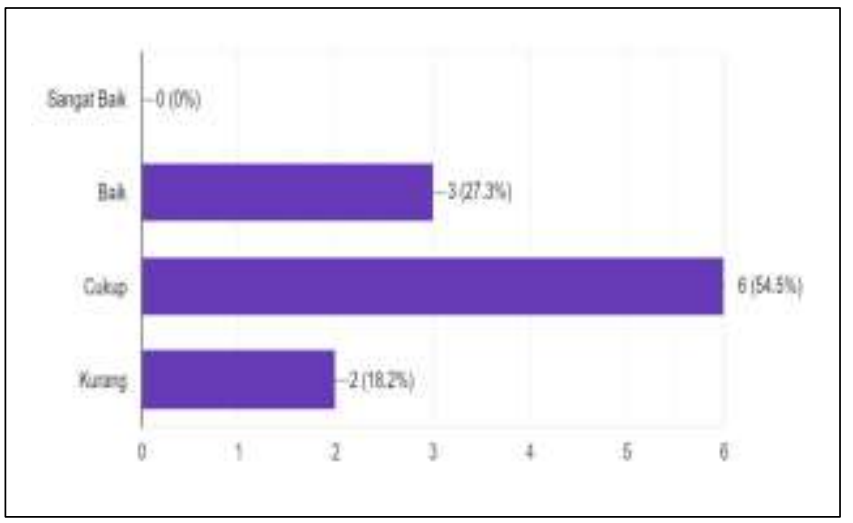

Before

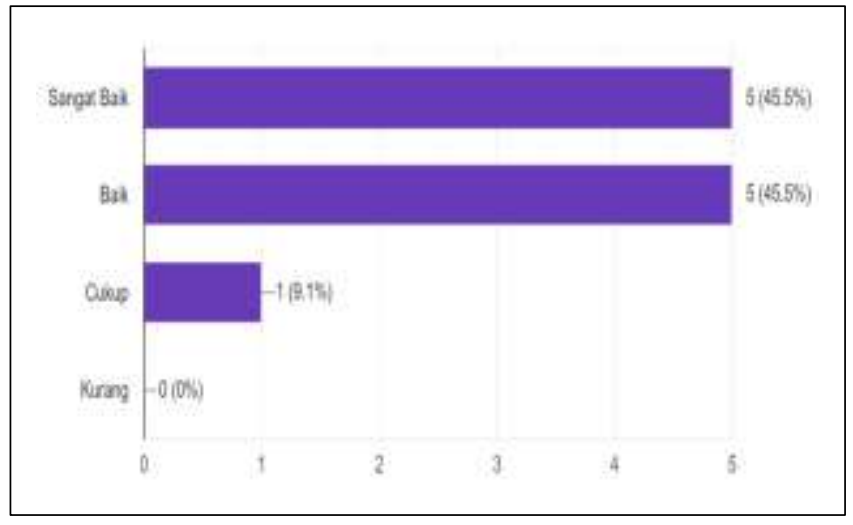

After

Figure 2: Teachers' Understanding of Journal Writing Before and After Training

Generally, the data from Figure 1 and Figure 2 show that this workshop has had a positive impact on the ability of the teachers to write scientific journals. It can be seen from the above data. Before training, 36.4\% of the participants indicated that they had a low motivation to write scientific journals. Only $9.1 \%$ of the participants were highly motivated. After training, the motivation of the participants increased considerably. 72.7 $\%$ of participants said they had a high motivation to write scientific journals. 
Data related to the growth of the teachers' understanding of writing scientific journals also moved positively. Before the training, the majority of participants $(54.5 \%)$ admitted that they had only sufficient insight into journal writing. After the training, $45.5 \%$ of the participants said they had a good understanding. A further $45.5 \%$ even said they had a very good understanding. Therefore, it can be concluded that this workshop was successful in transferring knowledge to the participants.

\section{CONCLUSION}

Academic writing skills which include an ability to publish in a scientific journal are necessary for teachers to carry out their professional duties. However, many teachers face problems in writing scientific journals. Therefore, a structured workshop with systematic content is needed to help teachers improve their scientific writing skills. This workshop activity was held for two months under a community service program, combining face-to-face classroom and online classroom. The workshop materials are quite compact, starting from general knowledge of scientific journal writing to technical matters on how to submit journals to the online journal system. The results of the workshop are relatively good, especially in terms of increasing the motivation of teachers and their understanding of the writing of scientific articles. Similar activities need to be carried out with the participation of more teachers.

\section{ACKNOWLEDGEMENT}

We would like to express our gratitude to the Rector and the Chair of the Institute of Research and Community Service (LPPM) of Universitas Riau which has provided financial assistance for these community service activities under the 2020 Integrated Service Activities (Kukerta Terintegrasi) Agreement No. 854 / UN.19.5.1.3 / PT.01.03/2020.

\section{REFERENCES}

Azizah, U. A., \& Budiman, A. (2017). Challenges in Writing Academic Papers for International Publication among Indonesian Graduate Students. Journal of English Education and Linguistics Studies, 4(2), 47-69. 
Bunyamin. (2016). Teacher professionalism: A study on teacher's professional and pedagogic competence at vocational high schools in the Northern Coastal of Jakarta. Indonesian Journal of Educational Research, 2(1), 77-84.

Daud, A. (2007, December 14). Guru Sebagai Peneliti, Mungkinkah? Kompas.

Eko Putro Widoyoko. (2008). Penelitian Tindakan Kelas dan Pengembangan Profesi Guru. Disajikan dalam Seminar Nasional Peningkatan Kualitas Profesi Guru Melalui Penelitian Tindakan Kelas. Seminar Nasional Peningkatan Kualitas Profesi Guru Melalui Penelitian Tindakan Kelas. Jogjakarta.

Keraf, G. (1996). Terampil Berbahasa Indonesia. Jakarta: Balai Pustaka.

Marwan, A. (2017). The Assessment of English Teachers' Ability to Write A Scientific $\begin{array}{lllll}\text { Article in } & \text { English. }\end{array}$ https://doi.org/10.21512/lc.v11i2.915

Nana Sudjana. (1987). Tuntunan Menyusun Karya Ilmiah. Bandung: Sinar Baru.

Nur Aisyah Zulkifli. (2016). Teachers' Ability in Writing Scientific Article. Kutubkhanah: Jurnal Penelitian Sosial Keagamaan, 19(1), 36-55.

Palmer, P. J. (1999). The Courage to Teach. College Composition and Communication. https://doi.org/10.2307/358975

Zemach, D. E., \& Lisa A. Rumisek. (2005). Academic Writing: From Paragraph to Essay. Edumond. 